\title{
【論文】
}

\section{廃衰物埋立地における放射性セシウムに対する 土壤吸脱着特性とその影響因子}

石 森 洋 行* . 遠藤和人* . 山田正人*.大迫 政 浩*

【要 旨】放射性物質に污染された廃棄物の焼却灰はその濃度によって埋立方法が異なるものの, 放射 性物質の拡散防止対策として土壤吸着層の設置は義務付けられており, その性能評価は重要である。本 研究では, 放射性セシウムに対する土壤や廃棄物, 吸着材等の吸着特性を把握するために, 放射能污染 飛灰から作製した 4 種類の飛灰溶出液を溶媒として，22 種類の試料を対象に吸着試験を行った。その 結果より分配係数を評価し，その影響因子を検討した。また試料に吸着した放射性セシウムの脱着特性 を調べるために, 純水, $1 \mathrm{~mol} / \mathrm{L}$ 酶酸アンモニウム, 人工海水，飛扊溶出液を溶媒とした溶出試験を行 い溶出率を評価した。

キーワード: 最終処分, 廃棄物, 焼却灰, 放射性セシウム, 土壤吸脱着

\section{1. は じめに}

2011 年 3 月 11 日に東日本大震災, 追随して津波が発 生した。津波は福島県東海岸にある福島第一原発を襲い, 冷却システムの供給電力が失われた。その結果, 核然料 収納被覆管のメルトダウンと 3 つの発電施設において水 素爆発が起こった。放射性物質（主に放射性セシウム） は大気中に広範囲に拡散し, 風によって流された。空か ら降下した放射性セシウムは地表面を污染させるだけで なく, 木や枝, 道路, コンクリート構造物, 農作物, 下 水污泥, 浄水污泥等のすべてのものを污染させた。焼却 は, 日本では廃较物を減容化するための手法として幅広 く用いられている。放射性セシウムで污染された廃棄物 を焼却した場合, 放射性セシウムは燒却灰と飛灰に濃縮 される。特に放射性セシウムは沸点が低く焼却時に揮発 するので, 焼却灰よりも飛灰に集中する。また飛灰中の 放射性セシウムは塩化セシウムの形態 (焼却時にガス化 されたセシウムと塩化物が結合することで形成される)

原稿受付 2016.4.25 原稿受理 2016.11.22

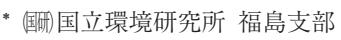

連絡先：干 963-7700 福島県田村郡三春町深作 10-2 傌伽国立環境研究所 福島支部石森 洋行 E-mail:Ishimori.hiroyuki@nies.go.jp
をもち，それは水に対して高い溶解度を示す。そのため， 放射性セシウムで污染された飛灰は, 埋立地では, 放射 性セシウムが降雨によって溶け出さないような工夫を施 して埋立処分を行う必要がある。

土壤は放射性セシウムに対して著しい吸着能力をもつ ことが知られている ${ }^{1)}$ 。放射性物質で污染された廃棄物 の下に土壤吸着層を敷設すると, 万が一廃棄物から放射 性セシウムが溶出した際には, 土壇吸着層によって放射 性セシウムを吸着できる。吸着は放射性セシウムの移動 を遅延できる上, 放射性セシウムには, 放射性セシウム 134 で半減期 2 年, 放射性セシウム 137 で半減期 30 年 の自然減衰をもつので, それらの濃度は遅延とともに減 少する。したがって土壤吸着層は放射性セシウムで污染 された廃棄物の最終処分技術の一つとして, 飛灰から溶 出する放射性セシウムの拡散を最小化するために有効で あると考えられる。

既往研究では, 塩化セシウム, または放射性セシウム の単一溶液を溶媒として用いて土壤吸着または脱着が調 ベられている ${ }^{2-6)}$ 。放射性セシウムの土壤吸着性や脱着 性は一般環境中の挙動としてはチェルノブイリ事故に関 するレポートでよく知られているものの ${ }^{7)}$, 高い $\mathrm{pH}$ 共存イオン濃度をもつ埋立地環境中での知見はほとんど ない。また土壤吸着層については, 覆土のように現地発 生土が利用されるため, 現地発生土が土壌吸着層に使用 
できるかどうかを判断するための指標を調べることが必 要である。本研究では, 数種類の土壤や廃棄物, 吸着材 等に対して吸着試験と脱着試験を行い, 最終的に, 廃棄 物埋立処分場における放射性セシウムの吸着性や脱着性 に及ぼす影響因子について議論した。

\section{2. 実 験 方 法}

\section{1 試 料}

実験には, 表 1 に示すように 22 種類の試料を使用し た。これらは2.1.1 土壤, 2.2 .2 廃棄物, および 2.2 .3 吸 着材の 3 種類に分類される。

\section{2 .1 土 壤}

吸着は試料の比表面積に依存するので，粒径の小さな
粘性土が多く含まれるほど吸着量は多いと考えられる。 そこで粒度分布が異なる土潩として，[\#1］けい砂 5 号 (単一粒径からなる標準砂), [\#2] 真砂土（花崗岩が風 化してできた砂質土），［\#3］川砂（大小さまざまな粒径 をもち特に砂分が多い砂質土)，[\#4]山砂（大小さまざ まな粒径からなる砂質土), [\#5～8] 処分場覆土 ST, MY, OS, SN（実際に処分場の覆土として使用されているも の), [\#9] カオリナイト (粘性土の代表として使用), [\#10] 関東ローム（高い含水量と有機物含有量をもつ日 本の特殊土), [\#11] ベントナイト（水和膨潤する粘性 土でありワイオミング産の $\mathrm{Na}$ 型モンモリロナイト）を 用いた。

\section{2 .2 廃 棄 物}

廃棄物試料には, [\#12～14] 建設発生土 TA, TB, TC

表 1 吸着試験・脱着試験に用いた試料の性状

\begin{tabular}{|c|c|c|c|c|c|c|c|c|c|c|c|c|}
\hline \multirow{2}{*}{\multicolumn{3}{|c|}{ 試料名 }} & \multirow{3}{*}{$\begin{array}{c}\begin{array}{c}\text { 土粒子 } \\
\text { の密度 } \\
\left(\mathrm{g} / \mathrm{cm}^{3}\right)\end{array} \\
2.67\end{array}$} & \multirow{3}{*}{$\begin{array}{c}\begin{array}{c}\text { 含水比 } \\
(\%)\end{array} \\
0.00 \\
\end{array}$} & \multirow{3}{*}{\begin{tabular}{|c|}
$\begin{array}{c}\text { 強熱減量 } \\
(\%)\end{array}$ \\
0.24 \\
\end{tabular}} & \multicolumn{4}{|c|}{ 粒度分布 } & \multirow{3}{*}{$\begin{array}{c}\begin{array}{c}\text { 比表面積 } \\
\left(\mathrm{m}^{2} / \mathrm{g}\right)\end{array} \\
1.5\end{array}$} & \multirow{3}{*}{$\begin{array}{c}\begin{array}{c}\text { 陽イオン } \\
\text { 交換容量 } \\
(\mathrm{cmol} / \mathrm{kg})\end{array} \\
0.7 \\
\end{array}$} & \multirow{3}{*}{ 同定された鉱物 } \\
\hline & & & & & & \multirow{2}{*}{\begin{tabular}{|c|}
$\begin{array}{c}\text { 粘土分 } \\
(\%)\end{array}$ \\
0.0 \\
\end{tabular}} & \multirow{2}{*}{$\begin{array}{c}\begin{array}{c}\text { シルト分 } \\
(\%)\end{array} \\
0.0 \\
\end{array}$} & \multirow{2}{*}{$\begin{array}{c}\begin{array}{c}\text { 砂分 } \\
(\%)\end{array} \\
100.0 \\
\end{array}$} & \multirow{2}{*}{$\begin{array}{c}\begin{array}{c}\text { 礫分 } \\
(\%)\end{array} \\
0.0 \\
\end{array}$} & & & \\
\hline \multirow{11}{*}{$\begin{array}{c}\text { a } \\
\pm \\
\text { 壤 } \\
\end{array}$} & $\# 1$ & けい砂 5 号 & & & & & & & & & & \\
\hline & $\# 2$ & 真砂土 & 2.64 & 0.01 & 1.34 & (未測定) & (未測定) & 39.8 & 53.0 & 2.9 & 4.1 & $\begin{array}{l}\text { 石英, 曹長石, 灰長石, 正 } \\
\text { 長石 }\end{array}$ \\
\hline & $\# 3$ & 川砂 & 2.61 & 11.45 & (未測定) & (未測定) & (未測定) & 65.2 & 22.8 & 15.7 & 9.1 & 石英, 灰長石, 方解石 \\
\hline & $\# 4$ & 山砂 & 2.77 & 2.84 & 2.52 & 2.7 & 8.1 & 49.2 & 40.0 & (未測定) & 8.3 & $\begin{array}{l}\text { 石英, 曹長石, 灰長石, 正 } \\
\text { 長石 }\end{array}$ \\
\hline & $\# 5$ & $\begin{array}{l}\text { 処分場覆土 } \\
\text { ST }\end{array}$ & 2.62 & 0.11 & 1.68 & (未測定) & (未測定) & 38.9 & 41.0 & 6.1 & 6.3 & $\begin{array}{l}\text { 石英, 曹長石, 灰長石, 正 } \\
\text { 長石 }\end{array}$ \\
\hline & $\# 6$ & $\begin{array}{l}\text { 処分場覆土 } \\
M Y\end{array}$ & 2.63 & 22.22 & 1.98 & (未測定) & (未測定) & 96.1 & 1.9 & 18.1 & 13.2 & 石英, 曹長石, 灰長石 \\
\hline & $\# 7$ & $\begin{array}{l}\text { 処分場覆土 } \\
\text { OS }\end{array}$ & 2.67 & 0.90 & 2.96 & (未測定) & (未測定) & 25.6 & 66.1 & (未測定) & 9 & $\begin{array}{l}\text { 石英, 曹長石, 灰長石, 正 } \\
\text { 長石 }\end{array}$ \\
\hline & $\# 8$ & $\begin{array}{l}\text { 処分場覆土 } \\
\text { SN }\end{array}$ & 2.68 & 14.37 & 5.02 & 7.1 & 21.8 & 511.1 & 20.0 & (未測定) & 11.1 & （未測定） \\
\hline & $\# 9$ & カオリナイト & 2.69 & 0.23 & 3.25 & 33.1 & 66.9 & 0.0 & 0.0 & 7.2 & 3.2 & 白雲母, 石英 \\
\hline & $\# 10$ & 関東ローム & 2.51 & 120.82 & 19.39 & 11.6 & 82.1 & 6.3 & 0.0 & 360.9 & 30.9 & 石英, 磁鉄鉱 \\
\hline & $\# 11$ & ベントナイト & 2.90 & 6.98 & 5.03 & 13.6 & 67.1 & 19.4 & 0.0 & 42.6 & 58.2 & モンモリロナイト, 方けい石 \\
\hline \multirow{8}{*}{$\begin{array}{l}\widehat{b} \\
\text { 廃 } \\
\text { 裹 } \\
\text { 物 }\end{array}$} & $\# 12$ & $\begin{array}{l}\text { 建設発生土 } \\
\text { TA }\end{array}$ & 2.58 & 74.63 & 9.09 & (未測定) & (未測定) & 64.9 & 17.6 & (未測定) & 49.8 & $\begin{array}{l}\text { 石英, 曹長石, 灰長石, 正 } \\
\text { 長石 }\end{array}$ \\
\hline & $\# 13$ & $\begin{array}{l}\text { 建設発生土 } \\
\text { TB }\end{array}$ & 2.63 & 69.98 & 8.47 & (未測定) & (未測定) & 92.5 & 0.4 & (未測定) & 21.4 & 石英, ハロイサイト \\
\hline & $\# 14$ & $\begin{array}{l}\text { 建設発生土 } \\
\mathrm{TC}\end{array}$ & 2.58 & 53.78 & 9.80 & (未測定) & (未測定) & 57.7 & 26.4 & (未測定) & 37.2 & $\begin{array}{l}\text { 石英, 曹長石, 灰長石, 方 } \\
\text { 解石 }\end{array}$ \\
\hline & $\# 15$ & $\begin{array}{l}\text { 津波堆積物 } \\
\text { IW }\end{array}$ & 2.55 & 33.80 & 19.15 & 9.4 & 27.4 & 37.4 & 25.8 & (未測定) & 9.6 & $\begin{array}{l}\text { 石英, 曹長石, 灰長石, 方 } \\
\text { 解石 }\end{array}$ \\
\hline & $\# 16$ & $\begin{array}{l}\text { 津波堆積物 } \\
\text { SN }\end{array}$ & 2.57 & 29.91 & 20.19 & 7.5 & 22.6 & 52.2 & 17.7 & 8.8 & 5.48 & （未測定） \\
\hline & $\# 17$ & 焼却灰 JS & 2.65 & 34.63 & (未測定) & 2.2 & 8.3 & 19.6 & 69.9 & 4.1 & 19.7 & (未測定) \\
\hline & $\# 18$ & 焼却灰 KW & 2.69 & 40.55 & 18.75 & 6.0 & 15.0 & 53.0 & 26.0 & 4.7 & 20.8 & (未測定) \\
\hline & $\# 19$ & 鉄鋼スラグ & 3.27 & 9.88 & 4.17 & (未測定) & (未測定) & 23.4 & 76.0 & (未測定) & 8.2 & (未測定) \\
\hline \multirow{3}{*}{$\begin{array}{l}\stackrel{(\mathrm{c}}{ } \\
\text { 吸 } \\
\text { 着 } \\
\text { 材 }\end{array}$} & $\# 20$ & $\begin{array}{l}\text { クリノプチロ } \\
\text { ライト }\end{array}$ & 2.44 & 3.14 & 3.12 & 6.1 & 18.5 & 65.5 & 9.9 & 4.7 & 67.9 & $\begin{array}{l}\text { 石英, 曹長石, 灰長石, 正長 } \\
\text { 石, クリノプチロライト }\end{array}$ \\
\hline & $\# 21$ & $\begin{array}{l}\text { 顆粒モルデ } \\
\text { ナイト }\end{array}$ & 2.31 & 0.05 & 1.11 & 0.0 & 0.0 & 0.0 & 100.0 & 159.3 & 140 & $\begin{array}{l}\text { 灰長石, 正長石, モルデナ } \\
\text { イト }\end{array}$ \\
\hline & $\# 22$ & $\begin{array}{l}\text { 粉末モルデ } \\
\text { ナイト }\end{array}$ & 2.38 & 0.06 & 1.57 & 17.2 & 62.5 & 20.3 & 0.0 & 104.1 & 130 & (未測定) \\
\hline
\end{tabular}


（処分場覆土として実際に再利用されている），［\#15〜 16]津波堆積物 IW, SN（東日本大震災による津波に よって発生したもの), [\#17～18］焼却灰 JS, KW（放 射性セシウムで污染された廃棄物を焼却した際に発生す るもの), [\#19] 鉄鋼スラグ（処分場覆土として再利用 されているもの）を用いた。

\subsection{3 吸着材}

吸着材には, [\#20]クリノプチロライト（栃木県産の 天然ゼオライト), [\#21] 顆粒モルデナイト（宮城県産 の粒径 1.4-4.0 mm の天然ゼオライト)，［\#22] 粉末モル デナイト（粒径 $0.2 \mathrm{~mm}$ 以下の天然ゼオライト）を用い た。

表 1 に土試料の物性を整理した。土粒子の密度は, JIS A 1202 に従い測定した。自然含水比は, JIS A 1203 に従い測定した。強熱減量はJIS A 1226 に従い測定し た。また粒径分布は, 礫分・砂分を多く含む試料につい てはJIS A 1204 に示されるふるい分析を行い, 一方で シルト分・粘土分を多く含む試料についてはレーザー回 折法（侏島津製作所 SALD-3100）を併用した。表中の 砂分とは粒径 $2 \mathrm{~mm}$ 以上, 砂分は $75 \mu \mathrm{m} \sim 2 \mathrm{~mm}$, シル 卜分は 5〜 75 $\mu \mathrm{m}$, 粘土分は $5 \mu \mathrm{m}$ 以下の粒子の割合で ある。比表面積は, Quantachrome Instruments Inc., の Quadrasorb SI を使用して窒素ガス吸着線に基づき 評価した。陽イオン交換容量および初期吸着イオンは Schollenberger and Shimon らの $\mathrm{NH}_{4} / \mathrm{K}$ 置換法に基づき 測定した。鉱物組成は, 粒径 $75 \mathrm{um}$ 以下に粉砕した試 料に対して PANalytical B. V.の X'Pert PRO MRD を用 いて X 線回折法に基づき決定した。

\section{2 吸着試験}

吸着試験の手順として，まず，試料を入れた $500 \mathrm{~mL}$ 容量のポリスチレン容器に, 溶媒を $300 \mathrm{~mL}$ 入れた。投 入した試料量は, その吸着能力を考慮して, 吸着材の場 合で 1〜 $\mathrm{g}$, 土壤および廃棄物の場合で 30 120 g とし た。その容器は $120 \mathrm{rpm}$ で 24 時間水平振とうした後, 容器内の液体は孔径 $0.45 \mu \mathrm{m}$ のセルロースアセテートメ ンブレンフィルタでろ過し，そのろ液の濃度を放射性セ シウムについてはゲルマニウム半導体検出器で, ナトリ ウム, カリウム, マグネシウム, カルシウム等について は ICP 発光分析で, 安定セシウムについては ICP-MS によって測定した。吸着試験前後のセシウムの濃度変化 から, 次式に従いセシウムの吸着量を計算した。

$$
S=\left(c_{0}-c_{e q}\right) \frac{V}{m}
$$

ここで $S$ は吸着量 $(\mathrm{Bq} / \mathrm{kg}$ または $\mathrm{mg} / \mathrm{kg}), \quad c_{0}$ は溶媒
の初期濃度 $(\mathrm{Bq} / \mathrm{L}$ または $\mathrm{mg} / \mathrm{L}), c_{e q}$ は溶媒の平衡濃度 $(\mathrm{Bq} / \mathrm{L}$ または $\mathrm{mg} / \mathrm{L}), \quad V$ は溶媒の体積 $(0.3 \mathrm{~L}), m$ は投 入した試料の質量 $(\mathrm{kg})$ である。また， [\#17] 焼却灰 JS と [\#18] 焼却灰 KW には放射性セシウムが含まれて いるが, 純水に対する溶出量は検出下限值未満 (10 $\mathrm{Bq} / \mathrm{L}$ 未満) であり吸着試験で用いる溶媒へ溶出する量 は無視できるほど少ない。そのため, 放射性セシウムを 含む焼却灰であっても溶出量が少なければ, 式 (1) と同 様に, 吸着試験前後の溶媒濃度の変化から吸着量を求め ることができる。

吸着試験は, 一つの試料に関して, 与える試料の質量 を 3 水準変化させて行った。セシウムの吸着量と平衡濃 度の関係から分配係数を算出した。分配係数の代表值は, 土試料の投入質量を 3 水準変化させた吸着試験の結果か ら, その線形回帰式の勾配として定義した。さらに吸着 量と平衡濃度の関係の直線性を調べるために, 投入質量 を 3 水準変化させた一つひとつの結果に対して, 平衡濃 度に対する吸着量の比として分配比を求め, 最大と最小 の分配比を分配係数のばらつきの指標として評価した。 なお異なる量の吸着材を溶媒に投入するため, それぞれ の平衡状態では共存イオンの組成が若干異なることから, 厳密には線形勾配を基に分配係数を算定することはでき ないが, ここでは蓋然性の高い分配係数を得る手法とし て採用した。

吸着試験の溶媒には, 放射性セシウムを含む水溶液を 得るために，放射性セシウムで污染された廃棄物を受け 入れ，焼却している 4 つの焼却施設から飛灰を採取し， その溶出液を用いた。具体的には採取した飛灰を, 液固 比 5 の条件で純水と混合し，プロペラつきの擋汼棒で 24 時間激しく擋拌し, その溶出液を孔径 $1 \mu \mathrm{m}$ のセル ロース䋊維ろ紙でろ過し, そのろ液それぞれに飛灰溶出 液 $\mathrm{ED}, \mathrm{JS}, \mathrm{MT}, \mathrm{KW}$ という名前をつけた。表 2 に作成し た吸着試験用溶媒の化学物質組成を示す。

\section{3 脱着試験}

飛灰溶出液 MT の 2 倍希釈用液を用いて, 脱着試験 に供する放射性セシウム污染試料を作製した。作製手順 は, 試料 $1 \mathrm{~kg}$ をポリエチレン製容器に量り取り, そこ へ液固比 5 になるように飛灰溶出液 MT 2 倍希釈液を加 えた。試料が懸濁する程度に緩やかに攪汼した後, 24 時間静置して飛灰溶出液中に緩く堆積した状態で放射性 セシウムを吸着させた。試料と上澄み液を分離して試料 の風乾を行い, 風乾後の試料を模擬污染試料とした。作 製した模擬污染試料を, 次の 2 とおりの脱着試験に供し た。

逐次脱着試験では，試料に吸着した放射性セシウムの 
表 2 吸着試験, 脱着試験に用いた液固比 5 飛灰溶出液の特性

\begin{tabular}{|c|c|c|c|c|c|c|}
\hline & 単仕 & & 吸着言 & 式験用 & & 脱着試験用 \\
\hline & 棵位 & 溶出液 ED & 溶出液 JS & 溶出液 MT & 溶出液 KW & 溶出液 NG \\
\hline $\mathrm{pH}$ & & 12.1 & 12.8 & 11.1 & 11.3 & 12.2 \\
\hline 電気伝導度 & $\mathrm{mS} / \mathrm{m}$ & 4,200 & 10,000 & 6,840 & 3,100 & 7,950 \\
\hline 放射性セシウム 134 & $\mathrm{~Bq} / \mathrm{L}$ & 712 & 610 & 1,200 & 90 & 0.78 \\
\hline 放射性セシウム 137 & $\mathrm{~Bq} / \mathrm{L}$ & 814 & 730 & 2,100 & 140 & 1.67 \\
\hline 安定セシウム & $\mathrm{mg} / \mathrm{L}$ & 0.3 & 0.52 & 0.77 & 0.33 & 0.36 \\
\hline 安定ストロンチウム & $\mathrm{mg} / \mathrm{L}$ & (未測定) & 6.78 & 3.22 & 4.34 & 15.1 \\
\hline ナトリウム & $\mathrm{mg} / \mathrm{L}$ & 3,040 & 8,430 & 9,250 & 4,240 & 9,880 \\
\hline カリウム & $\mathrm{mg} / \mathrm{L}$ & 5,500 & 9,590 & 13,100 & 5,100 & 7,800 \\
\hline マグネシウム & $\mathrm{mg} / \mathrm{L}$ & $<0.5$ & $<0.05$ & 0.58 & $<1.0$ & $<0.1$ \\
\hline カルシウム & $\mathrm{mg} / \mathrm{L}$ & 2,500 & 5,280 & 900 & 510 & 4,840 \\
\hline 塩素 & $\mathrm{mg} / \mathrm{L}$ & （未測定） & 27,700 & 26,450 & 15,500 & 29,800 \\
\hline
\end{tabular}

化学形態を推定することを目的として，溶媒には純水を 用いることで試料表面に付着した放射性セシウムの量を 水溶性画分として求め, さらにその試料に対して 1 $\mathrm{mol} / \mathrm{L}$ の酢酸アンモニウムを溶媒として脱着試験を行 うことで試料表面にカウンターイオンとイオン結合した 放射性セシウムの量をイオン交換態として評価する。具 体的な操作手順は高岡 $5^{8)}$ の示す逐次抽出試験法に準拠 して，(1)蓋付遠沈管に液固比 10 となるように，模擬污 染試料と純水を入れ, (2)室温 $20{ }^{\circ} \mathrm{C}$ で $200 \mathrm{rpm}, 6$ 時間 水平反復振とうを行った。(3)振とう終了後, 3,000 rpm で 10 分間遠心分離を行い, (4)上澄み液を $0.45 \mu \mathrm{m}$ セル ロース系メンブレンフィルタを用いて吸引ろ過した。(5) ここで得たろ液の $\mathrm{pH}, \mathrm{EC}$, 放射性セシウム, 金属イオン 等を測定し, 水溶性画分としての溶出濃度とした。6 遠沈管に残った試料に対して, 液固比 10 となるように $1 \mathrm{~mol} / \mathrm{L}$ 酢酸アンモニウム溶液を加え, (7)室温 $20{ }^{\circ} \mathrm{C}$ で $200 \mathrm{rpm}, 18$ 時間水平反復振とうを行った。(8)上澄み液 を $0.45 \mu \mathrm{m}$ セルロース系メンブレンフィルタを用いて吸 引ろ過を行い, (9)万液の $\mathrm{pH}, \mathrm{EC}$, 放射性セシウム, 金属 イオン等を測定し, イオン交換態の溶出濃度とした。

次に, 人工海水または飛灰溶出液を用いた脱着試験に ついては，海面埋立処分場に最終処分した污染土壤・污 染廃棄物等からの放射性セシウムの脱着性を調べるため に人工海水を用い，陸上埋立処分場では吸着した放射性 セシウムがそれよりも上部に埋め立られた廃棄物からの 浸出水によって洗い流されるおそれがあるので, そのと きの脱着性を調べるために飛灰溶出液を用いた。人工海 水には八洲薬品(株)アクアマリンを使用し, 飛死溶出液 には放射性セシウムを含まない飛灰から液固比 5 の条件 で作製したものを使用した。この飛灰溶出液を NGとラ ベルし, その組成は表 2 に示すとおりである。試験手順 は, (1)容量 3 L の蓋付ポリエチレン製容器に污染試料 $200 \mathrm{~g}$ を量り入れ，そこへ液固比 10 となるように, 人
工海水または飛灰溶出液を 2 L 加えた。(2)その後 200 $\mathrm{rpm}$ で, 6 時間水平反復振とうを行った。(3)振とう終了 後, 全液量について $3,000 \mathrm{rpm}$ で 10 分間の遠心分離を 行い, 遠心分離後の上澄み液全量に対して $0.45 \mu \mathrm{m}$ セル ロース系メンブレンフィルタを用いて吸引ろ過した。(4) ろ液について $\mathrm{pH}, \mathrm{EC}$, 放射性セシウム, 金属イオンの測 定を行い溶出量とした。

これらの脱着試験から得られた溶出濃度から, 次式を 用いて溶出率を算出した。

$$
\varepsilon=\frac{c}{\omega} \frac{V}{m} \cdot 100
$$

ここで, $\varepsilon$ は溶出率 $(\%), c$ は溶出濃度 $(\mathrm{Bq} / \mathrm{L}$ または $\mathrm{mg} / \mathrm{L}), w$ は含有量 $(\mathrm{Bq} / \mathrm{kg}$ または $\mathrm{mg} / \mathrm{kg}), V$ は溶媒 の体積 $(\mathrm{L}), m$ は投入した土試料の質量 $(\mathrm{kg})$ である。 ここで含有量は, 王水を用いて試料を酸分解しその分解 液中の化学物質濃度を測定することで求めた。

脱着試験に供した試料は次の 8 試料である。一般的な 砂質土としての挙動を調べるために[\#2]真砂土と [\#3］山砂を用いた。また, 実際の処分場覆土に用いら れている土壤として [\#6] 処分場覆土 MY と [\#8] 処分 場覆土 SNを使用した。粘性土としての挙動を調べるた めに関東圈に分布する [\#10]関東ロームを使用し, 廃 棄物としての挙動を調べるための [\#16]津波堆積物 SN と [\#18] 焼却疢 $\mathrm{KW}$, さらに吸着材としての挙動を調 ベるための $[\# 21]$ 顆粒モルデナイトを用いた。

\section{3. 吸着試験の結果}

\section{1 実験条件の決定}

全試料の吸着試験を行う前の予備的検討として, 吸着 試験に用いる溶媒の条件を決定するために, 放射性セシ ウムに対する土䁃や吸着材等の吸着能力に及ぼす $\mathrm{pH}$ の 
影響を調べた。溶媒には $\mathrm{pH}=12$ である飛灰溶出液 $\mathrm{ED}$ を純水で 2 倍に希釈した液体（液固比 10 の飛灰溶出液 に便宜上相当するとみなす）と，そこに少量の塩酸を追 加し $\mathrm{pH}=7$ に整えた液体を用いた。試料には一般的な 砂質土の挙動を調べるために，［\#1］けい砂 5 号と [\#2] 真砂土を用い，また実際の処分場覆土に用いられている 土壤として $[\# 5]$ 処分場覆土 ST を使用した。粘性土の 挙動を調べるための [\#11] ベントナイト, 吸着材の挙 動を調べるための [\#21］顆粒モルデナイトと [\#22] 粉 末モルデナイトを使用した。

図 1 に, $\mathrm{pH}=7$ と $\mathrm{pH}=12$ の飛灰溶出液に含まれる放 射性セシウム 137 に対する吸着等温線を示す。横軸に平 衡濃度, 縦軸に吸着量で整理したときのプロットの線形 勾配を分配係数と呼び，その值が大きいほど放射性セシ ウムに対する吸着性が高いことを意味する。表 3 に, 試 験結果から得られた分配係数と, $\mathrm{pH}=7$ の分配係数に 対する $\mathrm{pH}=12$ の分配係数の比を整理した。飛灰溶出液 中の放射性セシウムに対する吸着性は, [\#1] けい砂 5 号 $<[\# 2]$ 真砂土 $<[\# 5]$ 処分場覆土 ST $<[\# 11]$ ベント
ナイト $<[\# 21]$ 顆粒モルデナイト $<[\# 22]$ 粉末モルデナ イトの順に大きいことがわかった。土壤のなかでは砂分 よりもシルト分や粘土分が多くなるにつれて比表面積が 増えるので，シルト分や粘土分を多く含む [\#5]処分場 覆土 ST や $[\# 11]$ ベントナイトの分配係数は高くなった と考えられる。吸着材である [\#21] 顆粒モルデナイト と [\#22] 粉末モルデナイトは, [\#11] ベントナイトの 約 10 倍の分配係数をもち, 極女て高い吸着性をもつこ とがわかった。またこれらの分配係数は，[\#5］処分場 覆土 ST と $[\# 11]$ ベントナイトを除けば，溶液の $\mathrm{pH}$ が 中性とアルカリ性の場合でも分配係数の違いは $40 \%$ 以 内であった。 $[\# 5]$ 処分場覆土 ST と $[\# 11]$ ベントナイ トについては中性よりもアルカリ性の方が高い分配係数 を示し，放射性セシウム 137 に対して $[\# 11]$ ベントナ イトの場合 2.6 倍の分配係数比であった。これは粘性土 分の陽イオン交換容量がアルカリ性側で高くなるためだ と考えられる ${ }^{9,10)}$ 。なお，[\#1］けい砂 5 号において，放 射性セシウム 137 に対する分配係数が $\mathrm{pH}=7$ の場合で $0.9 \mathrm{~mL} / \mathrm{g}$ となっているが, 直線性の高い吸着等温線が

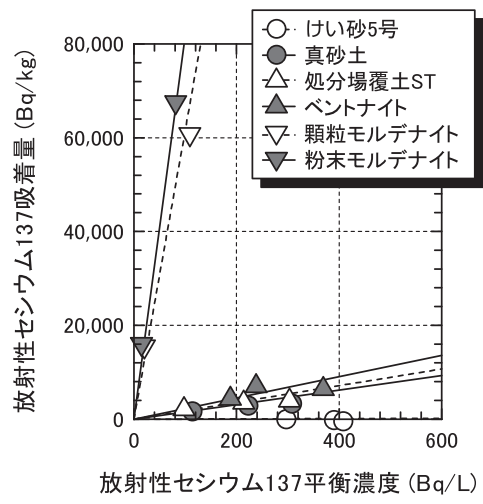

(a) $\mathrm{pH}=7$

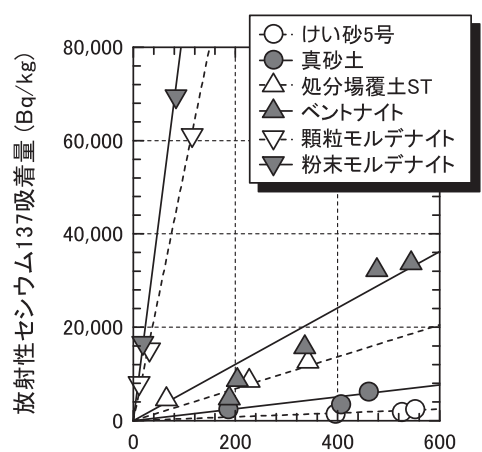

放射性セシウム 137 平衡濃度 $(\mathrm{Bq} / \mathrm{L})$

(b) $\mathrm{pH}=12$

図 1 異なる $\mathrm{pH}$ をもつ飛灰溶出液 $\mathrm{ED}$ に対する放射性セシウム 137 の吸着等温線

表 3 飛灰溶出液 $\mathrm{ED}$ の 2 倍希釈液*に対するセシウムの分配係数

\begin{tabular}{|l|c|c|c|c|c|c|c|c|c|}
\hline \multirow{2}{*}{} & \multicolumn{2}{|c|}{ 放射性セシウム $134(\mathrm{~mL} / \mathrm{g})$} & \multicolumn{2}{|c|}{ 放射性セシウム $137(\mathrm{~mL} / \mathrm{g})$} & \multicolumn{3}{|c|}{ 安定セシウム $(\mathrm{mL} / \mathrm{g})$} \\
\cline { 2 - 12 } & $\mathrm{pH}=7$ & $\mathrm{pH}=12$ & $\begin{array}{c}\text { 分配 } \\
\text { 係数比 }\end{array}$ & $\mathrm{pH}=7$ & $\mathrm{pH}=12$ & $\begin{array}{c}\text { 分配 } \\
\text { 係数比 }\end{array}$ & $\mathrm{pH}=7$ & $\mathrm{pH}=12$ & $\begin{array}{c}\text { 分配 } \\
\text { 係数比** }\end{array}$ \\
\hline けい砂 5 号 & 5.2 & 4.7 & 0.90 & $(0.9)^{* * *}$ & 4.8 & $(5.33)^{* * *}$ & 2.9 & 2.5 & 0.86 \\
\hline 真砂土 & 16 & 9.7 & 0.61 & 16 & 13 & 0.81 & 12 & 8.2 & 0.68 \\
\hline 処分場覆土ST & 31 & 36 & 1.16 & 19 & 35 & 1.84 & 15 & 25 & 1.67 \\
\hline ベントナイト & 41 & 51 & 1.24 & 24 & 63 & 2.63 & 16 & 38 & 2.38 \\
\hline 顆粒モルデナイト & 660 & 420 & 0.64 & 620 & 530 & 0.85 & 370 & 400 & 1.08 \\
\hline 粉末モルデナイト & 840 & 810 & 0.96 & 840 & 840 & 1.00 & 450 & 540 & 1.20 \\
\hline
\end{tabular}

* 飛灰溶出液 $\mathrm{ED}$ の 2 倍希釈溶液の電気伝導度は, $2,100 \mathrm{mS} / \mathrm{m}$ であった

** 分配係数比とは, $\mathrm{pH}=7$ の分配係数に対する $\mathrm{pH}=12$ の分配係数の比を表わす

**** 括弧内の数字は, 吸着等温線の直線性が悪く分配係数の信頼性が低いと思われるもの 
得られなかったので確実な数字であるとはいえない。 [\#1]けい砂 5 号のセシウムに対する吸着性は低く, 吸 着試験前後での溶媒中の放射性セシウム濃度に顕著な差 異が現れなかったため, 算出される吸着量にバラツキが 生じ直線性の高い吸着等温線が得られなかった。

次に, 溶媒の濃度条件を決定するために, 放射性セシ ウムの吸着特性に及ぼす溶媒濃度の影響として電気伝導 度を指標に評価した。溶媒には飛灰溶出液 ED の 2 倍希 釈液, 飛灰溶出液 JS の 2 10 倍希液と 5 倍濃縮液, 飛 灰溶出液 MT の 2 25 倍希釈液と 5 倍濃縮液, 飛灰溶 出液 KW の 5 倍濃縮液を用いた。ここで飛灰溶出液は 表 2 に示すように液固比 5 の条件で作製しているので, その 2 倍希釈液は便宜的に液固比 10 に相当するとみな す。一方で 5 倍濃縮液とは, 液固比 5 の飛灰溶出液を ホットプレートで加熱し, 水量の $90 \%$ を蒸発させた後 に孔径 $1 \mu \mathrm{m}$ のセルロース繊維ろ紙でろ過することで作 製した。この濃縮液は液固比 0.5 の溶出液に相当し, 埋 立地内の飛灰埋立層内の細かな間隙を通過した浸出水を
想定した。試料には, 同様に砂質土として挙動を調べる ために [\#1]けい砂 5 号, [\#2]真砂土, および [\#3]川 砂を用いるとともに, 粘性土としての挙動を調べるため に [\#9] カオリナイト, [\#11] ベントナイト, さらに吸 着材として $[\# 22]$ 顆粒モルデナイトを用いた。

図 2 に, 分配係数に及ぼす溶媒の電気伝導度の影響を 示す。溶媒の電気伝導度が増加するに従い, 分配係数は 小さくなった。これは試料の吸着容量には限りがあるた め, 放射性セシウムが試料に吸着する際, その吸着に競 合するイオンが溶媒中に存在すると放射性セシウムの吸 着量が制限されるためである。たとえば, Chang ら ${ }^{11)}$ によれば放射性セシウム 137 単一溶液に対するベントナ イトの分配係数は $6,200 \mathrm{~mL} / \mathrm{g}$ と報告されているが, 本 研究のように共存イオンをもつ飛灰溶出液に対しては, 電気伝導度が数百 $\mathrm{mS} / \mathrm{m}$ 以上の場合, 分配係数は約 $100 \mathrm{~mL} / \mathrm{g}$ 以下になった。分配係数が約 2 オーダー程度 も低くなり, 分配係数の低下に及ぼす共存イオンの影響 は著しいと考えられる。

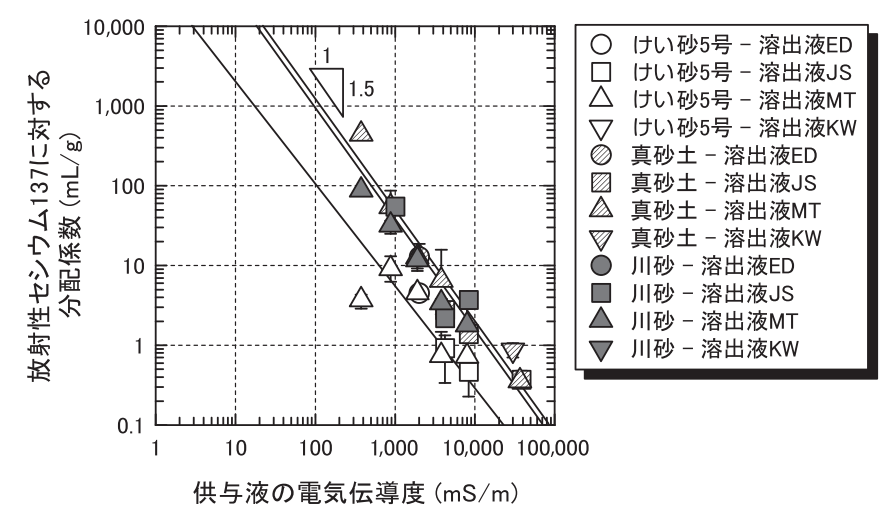

(a) 砂質土

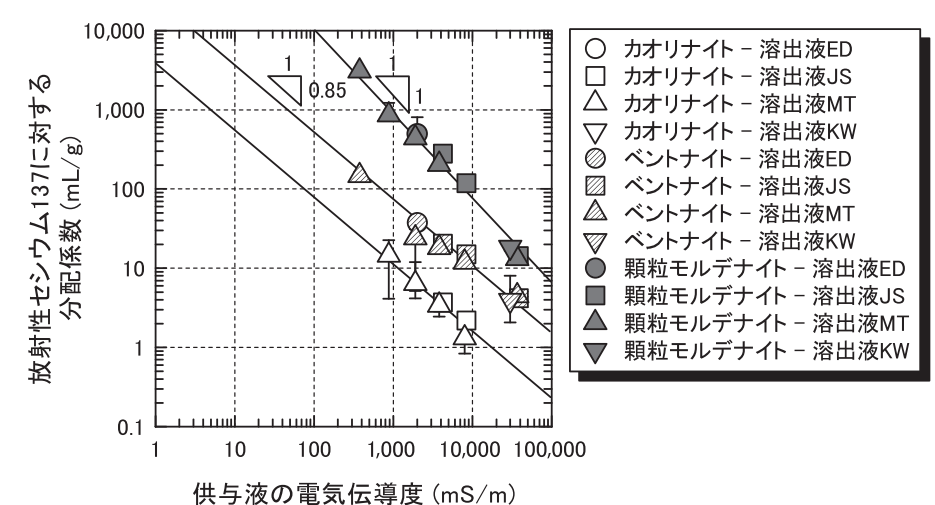

(b) 粘性土、モルデナイト

図 2 放射性セシウム 137 に対する分配係数と電気伝導度の関係 
電気伝導度に対する分配係数の低下は, 試料の種類に よって異なると考えられる。砂質土である [\#1）けい砂 5 号, [\#2] 真砂土, および $[\# 3]$ 川砂の場合, 溶媒の電 気伝導度が 1 オーダー増加するのに対して分配係数は約 1.5 オーダー低下した。一方, [\#21] 顆粒モルデナイト では電気伝導度 1 オーダーの増加に対して分配係数は約 1 オーダーの低下であり, 砂質土に比べると共存イオン による吸着阻害は受けにくいことがわかった。これは, ゼオライトの結晶構造においてイオンを抱え込める部位 の大きさが $0.3 \sim 0.8 \mathrm{~nm}$ であり, カルシウムやマグネシ ウム等の多価のイオンは水和時の大きさが $0.82 \sim 0.96$ $\mathrm{nm}$ であるため（水和したカリウムやセシウムの大きさ は $0.46 \mathrm{~nm}$ 程度), ゼオライトに取り込まれにくく吸着 阻害の影響が少なくなるためだと考えられる。また粘性 土では電気伝導度 1 オーダーの増加に対して分配係数は 約 0.85 オーダーの低下であり, 砂質土に比べると共存 イオンによる吸着阻害の影響は少ないことがわかった。

\section{2 全試料の分配係数}

3.1 に示した予備的検討の結果, 分配係数に及ぼす $\mathrm{pH}$ の影響は, 本研究で検討した試料では, 中性および アルカリ性において砂質土と吸着材ではほぼ同じであり, 粘性土ではアルカリ性のほうが高いことがわかった。ま た電気伝導度の影響については, 電気伝導度の増加に伴 い分配係数は低下し, その変化率は砂質土, 粘性土, お よび吸着材で異なることがわかった。分配係数に及ぼす
$\mathrm{pH}$ と電気伝導度の影響が明らかになったことから，全 試料の分配係数を調べるための吸着試験では, 溶媒の $\mathrm{pH}$ は塩酸による調整を必要としないアルカリ性に, ま た電気伝導度は一つの水準に固定することにした。

図 3 は, 本研究で用いた試料に対する分配係数を表わ す。溶媒は飛灰溶出液 JS の 2 倍希釈液（液固比 10 の飛 灰溶出液に便宜的に相当するとみなす）であり，その電 気伝導度は $4,210 \mathrm{mS} / \mathrm{m}$ であった。標準砂である [\#1] けい砂 5 号や標準粘土である [\#9] カオリナイトを除き, 土壤の分配係数は電気伝導度 $4,210 \mathrm{mS} / \mathrm{m}$ の液体に対し て約 $10 \mathrm{~mL} / \mathrm{g}$ を発揮した。また建設発生土や津波堆積 物, 焼却死においても同等の分配係数を示した。 $[\# 1]$ けい砂 5 号と [\#9] カオリナイトは不活性な石英を主要 鉱物とするため, 放射性セシウムに対する吸着性はその 他の試料よりも低かった。[\#19]鉄鋼スラグもまた放射 性セシウムに対する吸着性は認められなかった。放射性 セシウムに対して著しい吸着性を示したのは，[\#20］ク リノプチロライト, [\#21] 顆粒モルデナイト, [\#22] 粉 末モルデナイトであり, 共存イオンをもつ飛灰溶出液に おいてはゼオライト系の吸着材が放射性セシウムに対し て特異的に高い分配係数を示した。

\section{3 試料特性の影響}

土壤の分配係数に及ぼす試料粒径の影響を調べた。 土壤には $[\# 2]$ 真砂土, [\#7] 処分場覆土 OS および [\#14] 建設発生土 TCの 3 種類を用いて, それぞれをふ
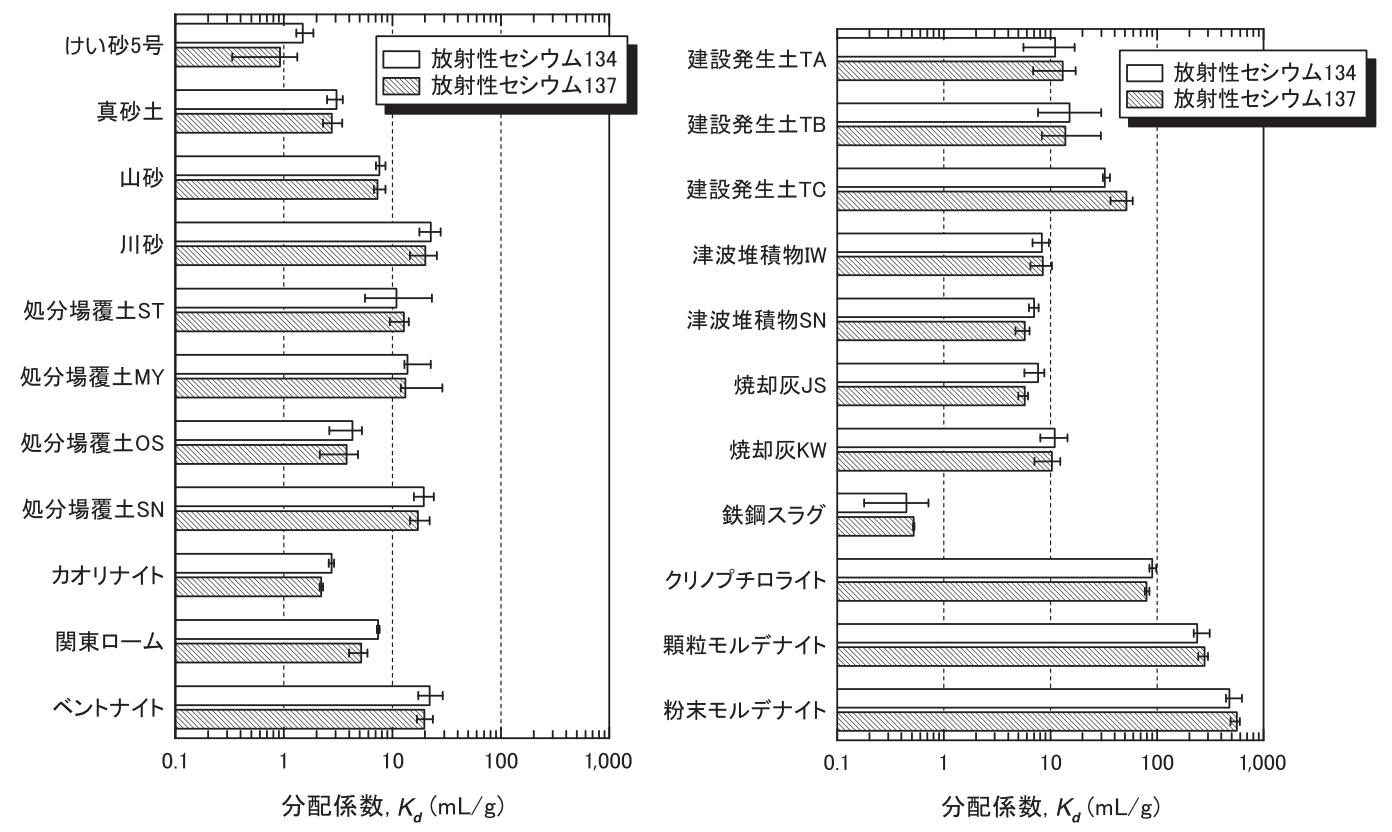

図 3 電気伝導度 $4,210 \mathrm{mS} / \mathrm{m}$ をもつ飛灰溶出液 JS に対する分配係数 
表 4 放射性セシウム 137 の分配係数と試料粒径の影響

\begin{tabular}{|l|c|c|c|c|c|c|c|c|c|}
\hline \multirow{2}{*}{ 粒度区分 } & \multicolumn{3}{|c|}{ 真砂土 } & \multicolumn{3}{c|}{ 処分場覆土 OS } & \multicolumn{3}{c|}{ 建設発生土 TC } \\
\cline { 2 - 11 } & $\begin{array}{c}\text { 比表面積 } \\
\left(\mathrm{m}^{2} / \mathrm{g}\right)\end{array}$ & $\begin{array}{c}\text { 分配係数 } \\
(\mathrm{mL} / \mathrm{g})\end{array}$ & $\begin{array}{c}\text { 分配 } \\
\text { 係数比* }\end{array}$ & $\begin{array}{c}\text { 比表面積 } \\
\left(\mathrm{m}^{2} / \mathrm{g}\right)\end{array}$ & $\begin{array}{c}\text { 分配係数 } \\
(\mathrm{mL} / \mathrm{g})\end{array}$ & $\begin{array}{c}\text { 分配 } \\
\text { 係数比* }\end{array}$ & $\begin{array}{c}\text { 比表面積 } \\
\left(\mathrm{m}^{2} / \mathrm{g}\right)\end{array}$ & $\begin{array}{c}\text { 分配係数 } \\
(\mathrm{mL} / \mathrm{g})\end{array}$ & $\begin{array}{c}\text { 分配 } \\
\text { 係数比* }\end{array}$ \\
\hline $2 \sim 4.75 \mathrm{~mm}$ & 1.19 & 2.80 & 1.00 & 1.86 & 3.82 & 1.00 & 30.0 & 18.6 & 1.00 \\
\hline $850 \mu \mathrm{m} \sim 2 \mathrm{~mm}$ & 2.04 & 3.57 & 1.28 & 1.46 & 7.06 & 1.85 & 32.6 & 20.8 & 1.12 \\
\hline $250 \sim 850 \mu \mathrm{m}$ & 2.78 & 6.54 & 2.34 & 7.01 & 13.9 & 3.65 & 59.7 & 28.5 & 1.53 \\
\hline $75 \sim 250 \mu \mathrm{m}$ & 4.84 & 12.6 & 4.50 & 8.11 & 15.0 & 3.93 & 64.7 & 28.0 & 1.50 \\
\hline $75 \mu \mathrm{m}$ 以下 & 11.2 & 21.5 & 7.69 & 11.6 & 19.8 & 5.19 & 62.6 & 27.7 & 1.49 \\
\hline
\end{tabular}

注：溶媒には飛灰溶出液 MT の 2 倍希釈溶液（電気伝導度 $3,800 \mathrm{mS} / \mathrm{m}$ ）を用いた

* 分配係数比とは粒度 $2 \sim 4.75 \mathrm{~mm}$ の分配係数を基準として, 他粒度の分配係数を比として表わしたもの

るいにかけ粒径 2 4.75 mm 画分, $850 \mu \mathrm{m} \sim 2 \mathrm{~mm}$ 画分, 250 850 $\mu \mathrm{m}$ 画分, $75 \sim 250 \mu \mathrm{m}$ 画分抢よび $75 \mu \mathrm{m}$ 以下 に分けた。各画分に対して, 飛灰溶出液 MT の 2 倍希 釈液（電気伝導度 $3,800 \mathrm{mS} / \mathrm{m}$ ）を溶媒として吸着試験 を行い, 放射性セシウム 137 に対する分配係数を調べた ところ表 4 の結果となった。

試料粒径が細かくなるにつれて分配係数は大きくなっ た。粒径 2 4.75 mm 画分の分配係数に対して, 粒径 75 $\mu \mathrm{m}$ 以下の分配係数の増加割合は土壤の種類によって異 なり，[\#2］真砂土においては 7.69 倍にも増加する一方 で, [\#14] 建設発生土 TC では 1.49 倍となり，いずれ の粒径画分においてもほぼ同じ分配係数を示した。これ は, 同じ土壤でも鉱物組成が異なれば比表面積や陽イオ ン交換容量が異なるためである。所要の分配係数をもつ 土壤を選定する場合, 鉱物組成の評価をなしに試料粒度 の从から規定することは難しいと考えられる。鉱物組成 の定量解析は容易ではないため, 定量性の高い比表面積 や陽イオン交換容量を指標に分配係数との関係を評価す るべきである。

図 3 に示した分配係数について, 比表面積または陽イ オン交換容量との関係を調べた。分配係数と比表面積の 関係を図 4 に, 陽イオン交換容量の関係を図 5 に示した。 なお, 全 22 試料のうち比表面積を測定していない試料 があるので, 図 4 中のプロット数は 22 よりも少なく なっている。放射性セシウムに対する分配係数は比表面 積と陽イオン交換容量に対して強い相関が認められた。 このことから, 所要の分配係数をもつ試料の条件を, 比 表面積と陽イオン交換容量を指標として規定できると考 えられる。たとえば, 放射性セシウム 137 の分配係数と して $10 \mathrm{~mL} / \mathrm{g}$ 以上を必要とする場合には, 試料の要件 として比表面積は $10 \mathrm{~m}^{2} / \mathrm{g}$ 以上, かつ陽イオン交換容 量は $10 \mathrm{cmol} / \mathrm{kg}$ 以上であることがわかる。

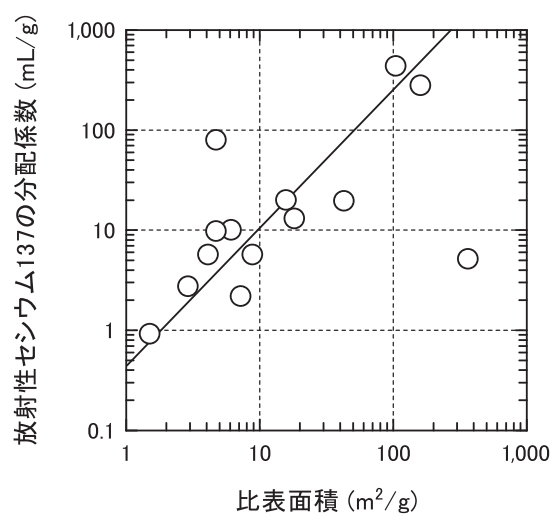

図 4 電気伝導度 4,210 $\mathrm{mS} / \mathrm{m}$ の飛灰溶出液に対する分 配係数と比表面積の関係

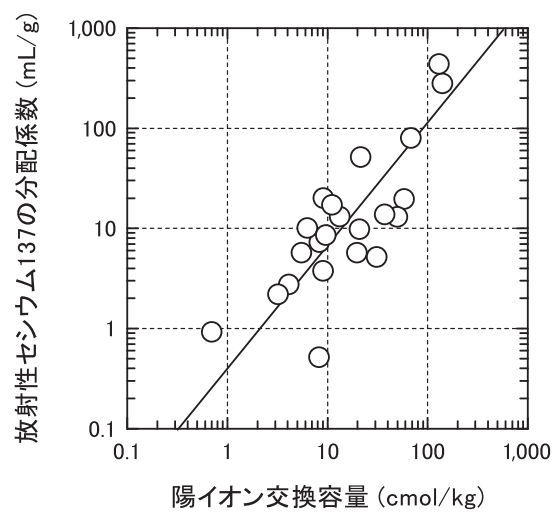

図 5 電気伝導度 $4,210 \mathrm{mS} / \mathrm{m}$ の飛灰溶出液に対する分 配係数と陽イオン交換容量の関係

\section{4. 脱着試験の結果}

作製した模擬污染試料の放射性セシウム含有量とその 溶出試験結果を表 5 に示す。また各模擬污染試料の溶出 量を図 6 に整理した。試料に一度吸着した放射性セシウ ムの脱着性は, 試料の種類によって大きく異なり, 
表 5 作製した模擬污染試料に含まれる放射性セシウム含有量とその溶出量

\begin{tabular}{|c|c|c|c|c|c|c|c|c|c|c|}
\hline & \multicolumn{2}{|c|}{ 含有量 $(\mathrm{Bq} / \mathrm{kg})$} & \multicolumn{8}{|c|}{ 溶出量 $(\mathrm{Bq} / \mathrm{L})$} \\
\hline & \multirow{2}{*}{$\begin{array}{c}\text { 放射性 } \\
\text { セシウム } \\
134\end{array}$} & \multirow{2}{*}{$\begin{array}{c}\text { 放射性 } \\
\text { セシウム } \\
137\end{array}$} & \multicolumn{4}{|c|}{ 放射性セシウム 134} & \multicolumn{4}{|c|}{ 放射性セシウム 137} \\
\hline & & & 純水 & $\begin{array}{c}1 \mathrm{~mol} / \mathrm{L} \\
\text { 酢安 }\end{array}$ & 人工海水 & $\begin{array}{c}\text { 溶出液 } \\
\text { NG }\end{array}$ & 純水 & $\begin{array}{c}1 \mathrm{~mol} / \mathrm{L} \\
\text { 酢安 }\end{array}$ & 人工海水 & $\begin{array}{c}\text { 溶出液 } \\
\text { NG }\end{array}$ \\
\hline 真砂土 & 1,020 & 2,030 & $<0.84$ & 7.26 & 4.00 & 13.0 & $<1.26$ & 18.2 & 7.95 & 26.2 \\
\hline 山砂 & 2,050 & 3,960 & $<0.90$ & 17.1 & 1.98 & 12.7 & 0.99 & 29.2 & 3.37 & 20.6 \\
\hline 処分場覆土 MY & 1,250 & 2,330 & 10.8 & 60.6 & 23.4 & 50.9 & 19.0 & 117 & 44.3 & 94.7 \\
\hline 処分場覆土 SN & 1,860 & 3,540 & 1.10 & 15.6 & 3.82 & 14.4 & 1.72 & 23.0 & 8.91 & 24.8 \\
\hline 関東ローム & 1,440 & 2,660 & 42.4 & 55.3 & 67.1 & 85.1 & 84.4 & 116 & 123 & 170 \\
\hline 津波堆積物 SN & 1,170 & 2,250 & 12.8 & 63.4 & 40.5 & 71.6 & 24.6 & 106 & 73.3 & 133 \\
\hline 焼却灰 KW & 1,570 & 2,940 & 95.1 & 92.1 & 55.3 & 83.0 & 26.3 & 177 & 107 & 150 \\
\hline 顆粒モルデナイト & 2,240 & 4,320 & $<0.84$ & 24.5 & 4.79 & 11.1 & $<1.09$ & 38.0 & 8.79 & 23.3 \\
\hline
\end{tabular}

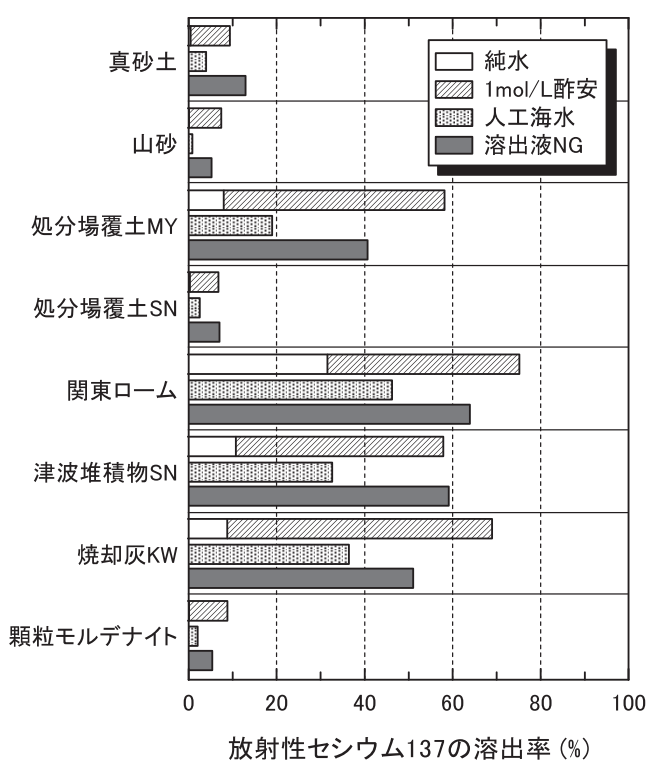

図 6 放射性セシウム 137 の溶出率

[\#2］真砂土や $[\# 4]$ 山砂，［\#8］処分場覆土 SN, [\#21］ 顆粒モルデナイトについては，いずれの溶媒に対しても 溶出率はおおむね $10 \%$ 以下であり小さい。それに対し て，［\#6］処分場覆土 MY や $[\# 10]$ 関東ローム， [\#16] 津波堆積物 SN, [\#18］焼却灰 $\mathrm{KW}$ は一部を除いて溶出 率 $40 \%$ 以上になった。放射性セシウムに対する吸着性 が高くても, その後の雨水等による洗い流しによっては 吸着した放射性セシウムが流出するおそれのあることが 示唆された。

溶出率に及ぼす溶媒の影響については, 純水よりも, 人工海水や飛灰溶出液 NG を用いたほうが溶出率は高く なった。人工海水と飛灰溶出液 NGにはイオン交換に寄 与する陽イオンは多く含まれているため, これらを溶媒 とした場合の溶出率は純水を用いた場合よりも高くなっ たと考えられる。イオン交換反応の優先順位は，水和半
径が小さいイオンほど優先的にイオン交換が行われると 考えられており, 中でもアンモニウムイオンやカリウム イオンの存在がセシウムの脱着に著しく影響するといわ れている。海水中のカリウム濃度は約 $380 \mathrm{mg} / \mathrm{L}$ であり, 一方の溶出液 NG のカリウム濃度は 7,800 mg/L である ことから, カリウムを多く含む溶出液 NG のほうが人工 海水よりも放射性セシウムの溶出率は高くなったと考え られる。

純水㧍よび $1 \mathrm{~mol} / \mathrm{L}$ 酢酸アンモニウムを溶媒とした 溶出率は, それぞれ試料に含まれる放射性セシウムの水 溶性画分の割合とイオン交換態の割合を表わす。その合 計值は, 人工海水または飛灰溶出液 NG を溶媒とした場 合よりも，真砂土の場合を除いて上回る結果となった。 処分場環境下では吸着した放射性セシウムがそれよりも 上部に埋め立てられた廃棄物からの浸出水によって洗い 流されるおそれがあるので, 吸着した放射性セシウムの 脱着性の評価は重要であるが, 純水および $1 \mathrm{~mol} / \mathrm{L}$ 酢 酸アンモニウムを溶媒とした溶出試験によって溶出しう る最大值を調べられると考えられる。

\section{5. 結 論}

廃棄物埋立処分場環境下における放射性セシウムの吸 脱着挙動を調べるために, 砂質土 ·粘性土 ·廃棄物 · 吸 着材等 22 種類の試料に対して, 吸着試験と脱着試験を 行ったところ以下の知見を得た。

(1) 放射性セシウムに対する分配係数は, 飛灰溶出液 を溶媒として用いた場合, $\mathrm{pH}$ には影響を受けな いが，電気伝導度には著しく左右される。砂質土 では電気伝導度が 1 オーダー増加すると分配係数 は約 1.5 オーダー低下した。粘性土や吸着材（モ ルデナイト）ではそれよりも影響は少なく，電気 伝導度が 1 オーダー増加すると分配係数は約 0.85〜1 オーダーの低下であった。 
(2) 電気伝導度 $4,210 \mathrm{mS} / \mathrm{m}$ をもつ飛灰溶出液に対す る放射性セシウムの分配係数は, けい砂 5 号とカ オリナイトを除き, 土壤であれば $10 \mathrm{~mL} / \mathrm{g}$ 程度 であった。建設発生土や津波堆積物, 焼却灰にお いても同程度の分配係数を発揮できることを確認 した。ゼオライト系の吸着材は放射性セシウムに 対して特異的に高い吸着性を示し，クリノプチロ ライトで $80 \mathrm{~mL} / \mathrm{g}$ 程度, 粉末モルデナイトで $500 \mathrm{~mL} / \mathrm{g}$ 程度の分配係数であった。

(3) 放射性セシウムに対する分配係数は, 比表面積と 陽イオン交換容量に対して強い相関性が認められ た。これを利用すれば，所要の分配係数をもつ試 料の要件として, 比表面積と陽イオン交換容量を 指標に規定できる可能性が示唆された。

(4) 試料に吸着した放射性セシウムの脱着性は, 純水 を溶媒とするよりも, 人工海水や飛灰溶出液を溶 媒とするほうが高い。これは一般環境中よりも， 陸上処分場や海面処分場内のほうが放射性セシウ ムは脱着しやすいことを意味する。真砂土・山 砂・モルデナイトの脱着性は溶出率としてお执 ね $10 \%$ 以下と低い值を示した。一方で関東ロー 厶や津波堆積物, 焼却灰では, 人工海水や飛灰 溶出液を溶媒とした場合, 溶出率は $40 \%$ 程度で あった。

\section{参考文献}

1) Y. Mahara: Storage and Migration of Fallout Strontium90 and Cesium-137 for Over 40 Years in the Surface, Soil of Nagasaki, Journal of Environmental Quality, Vol. 22, pp. $722-730$ (1993)
2) 井上頼輝, 森澤眞輔：放射性核種の土壤と水との間の 分配係数值, 原子力学会誌, 第 18 卷, 第 8 号, pp. 5262 (1976)

3 ）福井正美, 桂山幸典：飽和砂層内に扔けるCs および Sr イオンの吸着モデルに関する研究, 土木学会論文報 告集, 第 254 巻, pp. 37-48 (1976)

4 ) R. N. J. Comans, M. Haller and P. De Preter: Sorption of Cesium on Illite : Non-equilibrium Behavior and Reversibility, Geochimica et Cosmochimica Acta, Vol. 55, No. 2 , pp. 433-440 (1991)

5 ) C. N. Hsu, D. C. Liu and H.P. Cheng: Evaluation of Cesium Sorption on Natural Mordenite, Journal of Radioanalytical and Nuclear Chemistry, Vol. 185, No. 2, pp. 319-329 (1994)

6 ) H. Takami: Basic Study of 137Cs Sorption on Soil, Journal of Nuclear Science and Technology, Vol. 30, No. 12, pp. 1243-1247 (1993)

7 ) E. P. Petryaev, S. V. Ovsyannikova, I. Y. Lubkina, S. Y. Rubinchic and G. A. Sokolik : States of Chernobyl Radionuclides in Soils Outside the 30-km Zone, Geochemistry International, Vol. 31, No. 2, pp. 22-29 (1994)

8 ）高岡昌輝, 蔵本康宏, 武田信生, 藤原健史：逐次抽出 法による飛灰中亜鉛, 鉛, 銅抢よびカドミウムの化学 形態推定 土木学会論文集, 第 685 巻, VII-20, pp. 7990 (2001)

9 ）日本土壌肥料学会編：土壤の吸着現象——基礎と応用 一, 博友社, pp. 17-35 (2001)

10) S. Bayulken, E. Bascetin, K. Guclu and R. Apak: Investigation and Modeling of Cesium (I) Adsorption by Turkish Clays : Bentonite, Zeolite, Sepiolite, and Kaolinite, Environmental Progress \& Sustainable Energy, Vol. 30, No. 1, pp. 70-80 (2011)

11) K. P. Chang, C. N. Hsu and H. Tamaki : Basic Study of 137Cs Sorption on Soil, Journal of Nuclear Science and Technology, Vol. 30, No. 12, pp. 1243-1247 (1993) 


\title{
Characteristics of Soil Adsorption/desorption for Radioactive Cesium in Landfill Environments
}

\author{
Hiroyuki Ishimori*, Kazuto Endo*, Masato Yamada* and Masahiro Osako* \\ * Fukushima Branch, National Institute for Environmental Studies \\ ${ }^{\dagger}$ Correspondence should be addressed to Hiroyuki Ishimori : \\ Fukushima Branch, National Institute for Environmental Studies \\ (10-2 Fukasaku, Miharumachi, Tamura-gun, Fukushima 963-7700 Japan)
}

\begin{abstract}
In the final disposal of MSW incineration ash contaminated with radioactive cesium, installation of a soil adsorption layer is required to prevent the cesium from diffusing. This study investigated the soil adsorption/desorption characteristics for radioactive cesium in landfill environments. Soil adsorption tests were conducted for 22 kinds of samples, including soils, wastes, and absorbents using 4 kinds of MSW incineration fly ash leaching solutions. The distribution coefficients and the factors affecting them were investigated. Soil desorption tests were also conducted using pure water, $1 \mathrm{~mol} / \mathrm{L}$ ammonium acetate, artificial seawater, and fly ash leaching solution as solvents, showing their leachability of the radioactive cesium that had been adsorbed on the samples.
\end{abstract}

Keywords : final disposal, radioactive cesium, soil adsorption/desorption 